bile duct ligation. J Pediatr Gastroenterol Nutr 3:790-794

21. Salomon WL, Vreman HJ, Kwong LK, Stevenson DK 1986 Red cell destruction and bilirubin production in adult rats with short-term biliary obstruction. J Pediatr Gastroenterol Nutr 5:806-810

22. Schacter BA, Joseph E, Firneisz G 1983 Effect of cholestasis produced by bile duct ligation on hepatic heme and hemoprotein metabolism in rats. Gastroenterology 84:227-235

23. Weiss JS, Gautam A, Lauff JJ, Sundberg MW, Jatlow P, Boyer JL, Seligson D
1983 The clinical importance of a protein-bound fraction of serum bilirubin in patients with hyperbilirubinemia. N Engl J Med 309:147-150

24. Lauff JJ, Kasper ME, Wu TW, Ambrose RT 1982 Isolation and preliminary characterization of a fraction of bilirubin in serum that is firmly bound to protein. Clin Chem 28:629-637

25. Breslow E, Chandra R, Kappas A 1986 Biochemical properties of the heme oxygenase inhibitor, Sn-protoporphyrin. Interactions with apomyoglobin and human serum albumin. J Biol Chem 261:3135-3137

\title{
Announcement International Symposium on Growth Abnormalities
}

An International Symposium on growth abnormalities will be held in Bologna, Italy, June 22-24, 1988. Main topics: physiology of growth and growth disturbances (growth hormone deficiencies, genetic, adrenogenital, and Turner's syndromes, celiac, and onco-hematologic diseases) GH, GRF, and alternative treatments for growth failure.

The symposium falls within the celebration of the 9th Centenary of the University of Bologna and it will include lectures by invited speakers and selected oral and poster presentations.

Scientific committee: E. Cacciari (I), J. R. Bierich (FRG), S. Raiti (USA).

The deadline for submission of abstracts is March 15, 1988.

For further informations please contact: Scientific Secretariat, International Symposium on Growth Abnormalities, Clinica Pediatrica II dell'Università, Via Massarenti, 11, 40138 Bologna, Italy. 